American Journal of Biochemistry and Biotechnology 7 (2): 90-103, 2011

ISSN 1553-3468

(C) 2011 A.E. Ghaly et al., This open access article is distributed under a Creative Commons Attribution

(CC-BY) 3.0 license

\title{
Biodegradation of Phenolic Compounds in Creosote Treated Wood Waste by a Composting Microbial Culture Augmented with the Fungus Thermoascus aurantiacus
}

\author{
Abdel E. Ghaly, Bopeng Zhang and Deepika Dave \\ Department of Process Engineering and Applied Science, \\ Dalhousie University, Halifax, Nova Scotia, Canada
}

\begin{abstract}
Problem statement: Creosote is used as a wood preservative and water proof agent in railway sleepers, utility poles, buildings foundations and fences and garden furniture. It is a mixture of over 300 hydrocarbons which include $75 \%$ polycyclic aromatic hydrocarbons, $2-17 \%$ phenolic compounds and 10-18\% heterocyclic organic compounds. Exposure to creosote may result in several health problems including damage to kidney, liver, eyes and skin. Potential contamination of soil and water exist from creosote treated wood from construction and demolition sites. Approach: The possibility of using an invessel composting process augmented with the ascomycetous fungus Thermoascus aurantiacus as a mesophilic/thermophilic bioremediation option for the degradation of phenolic compounds in creosote treated wood waste was evaluated. Results: The temperatures of bioremediation process reached thermophilic phase and the mesophilic and thermophilic lag phases were clearly identified. The moisture content decreased significantly indicating that the water produced by microbial respiration did not compensate for the water lost as vapor with the exhaust gases. Initial increases in $\mathrm{pH}$ due to the breakdown of organic nitrogen to ammonium and final drop in $\mathrm{pH}$ due to the formation of organic acids and the loss of ammonium with the exhaust gases in the latter stage were observed. Different degradation rates were observed in the mesophilic and thermophilic stages of composting. The control experiment achieved higher reductions of volatile solids, total carbon and TKN and higher degradation of phenolic compounds, cellulose and lignin, indicating a higher level of activity of microorganisms during the composting process compared with the inoculated experimental trial. The stability and maturity of the product of the control experiment were also better than those of the product from the inoculated experimental trial. Conclusion: The inoculation of the cellulolytic-thermophilic fungus Thermoascus aurantiacus did not accelerate the bioremediation process in degrading phenolic compounds and the fungus may have inhibited the growth and metabolic activities of composting organisms.
\end{abstract}

Key words: Composting process, bioremediation bioremediation, phenolic compounds, wood waste, Thermoascus aurantiacus, Moisture Content (MC), Polycyclic Aromatic Hydrocarbons (PAHs), Total Kjeldahl Nitrogen (TKN)

\section{INTRODUCTION}

Creosote is distilled from crude coke oven tar consisting of around $75 \%$ of Polycyclic Aromatic Hydrocarbons (PAHs), 2-17\% phenolic compounds, $10-18 \%$ heterocyclic organic compounds and minor aromatic amines. However, because of different sources and preparation procedures in manufacturing processes, the components of creosote may vary in concentration as well as type (ATSDR, 2002). Creosote is widely used as a preservative of wood products and waterproofing agent (Bedient et al., 1984; CEPA, 1994; ATSDR, 2002). Creosote-treated wood has been widely used in railway sleepers, utility poles, buildings foundations, building fences, bridges stakes for agricultural and fruit products, garden furniture and outdoor recreational facilities in parks (CICAD, 2004; Ikarashi et al., 2005).

Creosote is toxic to human being and has carcinogenic and genotoxic potentials due to the presence of PAHs as the main component of creosote (ATSDR, 2002; CICAD, 2004). Phenolic compounds contained in creosote are also carcinogens and are toxic to aquatic living creatures (CICAD, 2004). Because of its toxicity, creosote-treated wood does not degrade easily in the environment and requires special disposal

Corresponding Author: Abdel E. Ghaly, Department of Process Engineering and Applied Science, Dalhousie University, Halifax, Nova Scotia, Canada Tel: (902) 494-6014 
methods. A possible disposal option is incineration which is problematic because of the release of components such as PAHs and furans (CICAD, 2004). The pollutants contained in the creosote-treated wood waste are also barriers to its use as landfill cover due to potential migration of contaminants into ground water. Therefore, a proper disposal method should include an effective degradation of the pollutants in creosotetreated wood waste.

Composting (as a bioremediation technique) has the advantage of degrading wood waste. Through mineralization and humification, the wood waste can be converted into a substance rich in humus and plant nutrients while at the same time result in reducing the volume of the final product. If the contaminants in the waste are degraded during composting, the final product could be used as a soil amendment (Loser et al., 1999; Borazjani et al., 2000; McMahon et al., 2008). However, a stable product requires a long period of temperature higher than $55^{\circ} \mathrm{C}$. Although the temperature during thermophilic phase of composting could reach $70^{\circ} \mathrm{C}$ which indicates a fast degradation of organic matter inside the composting pile, the phase typically lasts no longer than 2-3 days while a maturing phase of at least 3 weeks is required to result in a stable and mature compost product (Haug, 1993; CCME, 2005; Gajalakshmi and Abbasi, 2008). In order to accelerate the maturing process, a controlled prolonged thermophilic phase is needed.

The inoculation of cellulolytic microorganisms may help to achieve a fast bioremediation process. Given that mesophilic cellulolytic microorganisms would be severely deactivated under temperature higher than $37^{\circ} \mathrm{C}$, thermophilic fungi or bacteria would serve as better decomposers under elevated temperature environment (Cooney and Emerson, 1964). The thermophilic ascomycetous fungus Thermoascus aurantiacus can produce all cellulolytic enzymes required for complete degradation of cellulose to glucose (Brienzo et al., 2008). Cellulolytic enzymes produced by Thermoascus aurantiacus (especially endo-glucanase) have been applied in industrial production because of their superior thermostability, high rates of substrate hydrolysis and stability over a wide range of $\mathrm{pH}$ vaues (Mamma et al., 2009; Yu et al., 1987).

The main aim of this study was to evaluate the possibility of using a composting process augmented with the ascomycetous fungus Thermoascus aurantiacus as a bioremediation option to facilitate the degradation of phenolic compounds in creosote treated wood waste. Phenolic compounds were chosen as the target contaminants because extensive studies have been conducted on PAHs, but few reports were focusing on phenolic compounds.

\section{MATERIALS AND METHODS}

Experimental apparatus: The experiments were carried out in a specially designed multiple bioreactor composting/bioremediation system (Fig. 1). Three bioreactors were horizontally fastened into a main frame. Each bioreactor was made of a polyvinyl chloride cylinder (PVC/711, IPS Corporation, Gardena, CA). The cylinder had an inside diameter of $203 \mathrm{~mm}$, a length of $520 \mathrm{~mm}$ and a wall thickness of $5 \mathrm{~mm}$ which provided a space for $3.5 \mathrm{~kg}$ (wet-basis) of the compost mixture plus $25 \%$ of the volume as a head space. A fixed circular PVC plate of $203 \mathrm{~mm}$ diameter and $6 \mathrm{~mm}$ thickness was glued into the back end of the cylinder. A removable circular plexiglas plate of $203 \mathrm{~mm}$ diameter and $6 \mathrm{~mm}$ thickness was installed on the front end of the cylinder. A circular window of $64 \mathrm{~mm}$ diameter was left on the removable circular plate for sampling purposes. The window was closed with a rubber stopper (No. 13) when it was not in use. The cylinders were insulated with a $38.1 \mathrm{~mm}$ thick Fibreglass while the removable circular plates were insulated with a $38.1 \mathrm{~mm}$ thick Styrofoam layer.

Each bioreactor had three holes at the bottom which were used for supplying air to the bioreactor. A top hole was used for the exhaust gas. The pressure regulated air passed through a desiccator and then through a flow meter (No 32461-14, Cole-Parmer Instrument Company, Vernon Hills, Illinois, USA). The flow meter had a $10 \mathrm{~cm}$ (4-inch) scale and a range of 0.0566-0.566 $\mathrm{m}^{3} \mathrm{~h}^{-1}$ (2-20 standard cubic feet per h.). When the gas left the bioreactor, it passed through a scrubber that contained water to get rid of aerosol and water soluble organic compounds, then through another scrubber to eliminate possible airborne $\mathrm{PAH}$ compounds in the exhaust gas.

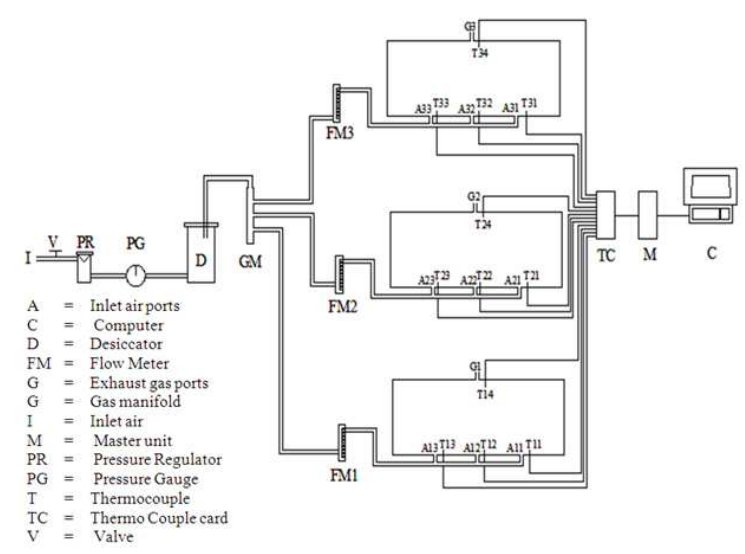

Fig. 1: The experimental set up of the bioremediation system 


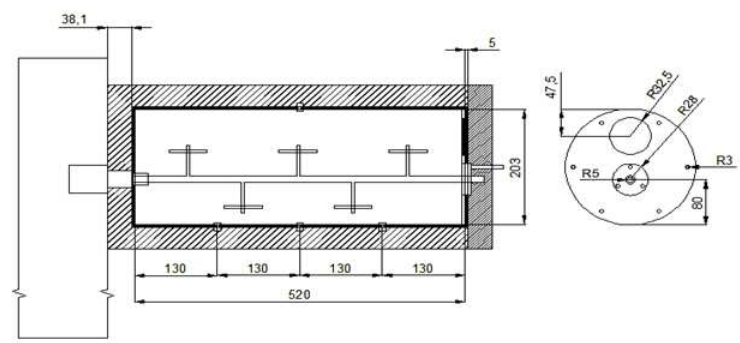

Fig. 2: Bioreactor (dimensions in $\mathrm{mm}$ )

Table 1: Components for potato dextrose agar and potato dextrose broth

\begin{tabular}{lll}
\hline Component & $\begin{array}{l}\text { Potato Dextrose } \\
\text { Agar (PDA) }\end{array}$ & $\begin{array}{l}\text { Potato } \\
\text { dextrose broth }\end{array}$ \\
\hline Distilled water & $1.0 \mathrm{~L}$ & $1.0 \mathrm{~L}$ \\
Agar & $15.0 \mathrm{~g}$ & $/$ \\
Potato dextrose powder & $24.0 \mathrm{~g}$ & $24.0 \mathrm{~g}$ \\
\hline $\begin{array}{l}\text { The agar and potato dextrose powder } \\
\text { aldrich, St. Louis, Missouri }\end{array}$
\end{tabular}

Inside each bioreactor, a removable $10.5 \mathrm{~mm}$ diameter solid stainless steel shaft was mounted on two bearings. There were 5 stainless steel collars on the shaft (Fig. 2). A bolt of $69 \mathrm{~mm}$ in length and $6 \mathrm{~mm}$ in diameter was mounted on each collar. A thermally protected electric motor (Model No. 127P1486/B, D. C., Sigma Instruments Inc., Braintree, Mass, USA) provided power to rotate the mixing shaft at speed of $6 \mathrm{rpm}$.

The data acquisition unit consisted of a master unit (Multiscan 1200, Omega, Stamford, CT), thermocouple/volt scanning card (MTC/24, Omega, Stamford, CT), Tempview software (Omega, Stamford, $\mathrm{CT}$ ), temperature sensors (type $\mathrm{T}$ thermocouples, Cole Parmer, Chicargo, IL) and a personal computer (Pentium IV, $256 \mathrm{MB}$ of RAM). The thermocouples were inserted through specially constructed fitting. The thermocouples on the bottom of all bioreactors were located far enough from the inlet air ( $65 \mathrm{~mm}$ away) to minimize the negative influence of inlet air temperature.

Collection and preparation of wood waste: The $\mathrm{C}$ and D wood waste was obtained from $C$ and D site in Yartmouth, Nova Scotia. It was screened to remove visible non-biodegradable materials and was sieved using USA Standard Testing Sieve with $12.5 \mathrm{~mm}$ opening (USA Standard Testing Sieve, ATM, Milwaukee, Wisconsin). Then, the wood chips were well mixed with fresh compost (Miller Compost Corporation, Dartmouth, NS) at a ratio of 1:1. The C: $\mathrm{N}$ ratio was adjusted using urea $\left[\mathrm{CO}\left(\mathrm{NH}_{2}\right)_{2}\right]$ and the moisture content was adjusted to $60 \%$ using distilled water.
Preparation of inoculums: Thermoascus aurantiacus (ATCC 204492) was obtained from the Manassas, Virginia and used as inoculum in one of the experiments. Potato Dextrose Agar (PDA) medium was used for slants and Petri dishes and potato dextrose broth was used as liquid medium. Both solid and broth media were made in the laboratory using distilled water and the reagents listed in Table 1 . The steps for preparing the Thermoascus aurantiacus spore suspension are showing in Fig. 3. The freeze dried culture was hydrated in dextrose broth and then plated on dextrose agar. After $24 \mathrm{~h}$, colonies with bright orange color start forming on the dextrose agar (Fig. 4a). Spore suspension of Thermoascus aurantiacus was prepared by cutting $1 \mathrm{~cm}^{2}$ Petri dish culture into 25 mLsterile potato dextrose broth medium and incubating in an incubator (Isotemp® oven, Model 106G, Fisher Scientific, Hampton, New Hampshire) at $45^{\circ} \mathrm{C}$ in order to activate the fungal culture. After $48 \mathrm{~h}$ of incubation, plate counts were conducted to detect Colony Forming Units (CFU). An amount of $5 \mathrm{mLmedia}$ containing the CFU of $2.0 \times 104 \mathrm{~mL}^{-1}$ was transferred into Fernbach flasks containing 250 mLof liquid cultural media and agitated on rotary shaker (Series G-25 Incubator Shaker, New Brunswick Company, New Jersey, USA) at $120 \mathrm{rpm}$ and $45^{\circ} \mathrm{C}$ for $48 \mathrm{~h}$.

Figure $4 \mathrm{~b}$ shows a higher magnification of asci containing ascospores. The final cultures were used as inoculums in the experiment in the amount of $10 \%$ (by weight) of composting mixture (wood waste+municipal solid waste compost).

Experimental protocol: Approximately $3 \mathrm{~kg}$ of the final mixture were placed in each bioreactor. Two experiments were carried out: (a) A control experiment with the no fungus Thermoascus aurantiacus added and (b) An experiment with the fungus Thermoascus aurantiacus added to the mixture. Three replicates were conducted for each experiment using the three bioreactors simultaneously. Each group of experiments lasted for 15 days. The pressure-regulated air was supplied continuously to the bottom of the bioreactor. The flow rate was measured by a flow meter (No 32461-14, Cole-Parmer Instrument Company, Vernon Hills, Illinois, USA) and adjusted to $0.05 \mathrm{~m}^{3} \mathrm{~h}^{-1}(3 \mathrm{~V} \mathrm{~V}$ $\mathrm{h}^{-1}$ ). Temperature was monitored throughout the process and the data was stored in a Microsoft Excel® file in the computer every $30 \mathrm{~min}$. The temperature of each experimental group was then generated using average temperature from 12 thermocouples in three 
bioreactors. An amount of $36 \mathrm{~mL}$ used cooking oil were added into the bioreactor every $12 \mathrm{~h}$ for the duration of each experiment as recommended by Alkoaik (2005). This was done in order to achieve a thermophilic condition of $60^{\circ} \mathrm{C}$. The $\mathrm{pH}$ and moisture content were also monitored. After 15 days of bioremediation, the quality, degradation of cellulose and lignin, the degradation of phenolic compounds and the quality, stability and maturity of the end product were evaluated. The quality of the end product was determined by quantifying $\mathrm{C}: \mathrm{N}$ ratio, $\mathrm{pH}, \mathrm{CO}_{2}$ evolution, phytotxicity.

Moisture content and pH: The Moisture Content (MC) was measured following the ASTM (D4442-07) oven-drying method (ASTM, 2007a). Slurry contained about $10 \mathrm{~g}$ of material and $50 \mathrm{mLdistilled} \mathrm{water} \mathrm{was}$ used to measure the $\mathrm{pH}$ value using a $\mathrm{pH}$ meter (Fisher Accumet ${ }^{\circledR}$, Model 805 MP, Fisher Scientific, Hampton, New Hampshire).

Total carbon: Approximately $1.0 \mathrm{~g}$ of the material was sampled for total carbon analysis. Carbon dioxide was determined with a Leco carbon analyzer (Model 516000, Leco Corporation, St. Joseph, Michigan) along with an induction furnace (Leco HF2O Furnace, Leco Corporation, St. Joseph, Michigan) at the Mineral Engineering Centre of Dalhousie University, Halifax, Nova Scotia.

Solids: The solids analyses were performed according to the procedures described in the USEPA Method 1684
(USEPA, 2001). Ash contents were determined by burning samples in muffle furnace (Isotemp® Muffle Furnace, Model 186A, Fisher Scientific, Hampton, New Hampshire) at a temperature of $550^{\circ} \mathrm{C}$ for $20 \mathrm{~min}$.

Total Kjeldahl Nitrogen (TKN): The Total Kjeldahl Nitrogen (TKN) was determined at Maxxam Analytical Testing Laboratory in Mississauga, Ontario, following the procedure of USEPA Method 351.2 (USEPA, 1993).

Phenolic compounds: The phenolic compounds were extracted from $3 \mathrm{~g}$ material with $50 \mathrm{mLdeionized} \mathrm{water}$ and centrifuged for $20 \mathrm{~min}$ at $2400 \mathrm{rpm}$. The supernatant was vacuum filtered through a $0.4 \mu \mathrm{m}$ polycarbonate filter paper $(47 \mathrm{~mm}$ diameter polycarbonate filter paper, Fisher Scientific, Montreal, Quebec) as described by Carter and Gregorich (2008). The supernatant was transferred into a flask and analyzed for the presence of phenolic compounds using the 4-aminoantipyrine colorimetric test following the ASTM procedure (ASTM, 2007b) at $510 \mathrm{~nm}$ using spectrophotometer (Spectronic 601, Milton Roy, Ivyland, PA). A standard curve was prepared as shown in Fig. 5. The linear relationship of phenolic compounds concentration to the absorbance reading at $510 \mathrm{~nm}$ was described by Eq. $1\left(\mathrm{R}^{2}=0.9972\right)$ :

\section{$\mathrm{AU} 510=0.0908 \mathrm{PC}$}

Where:

AU510 = Absorbance reading at $510 \mathrm{~nm}$

$\mathrm{PC}=$ Concentration of phenolic compounds $(\mathrm{mg} / \mathrm{L})$

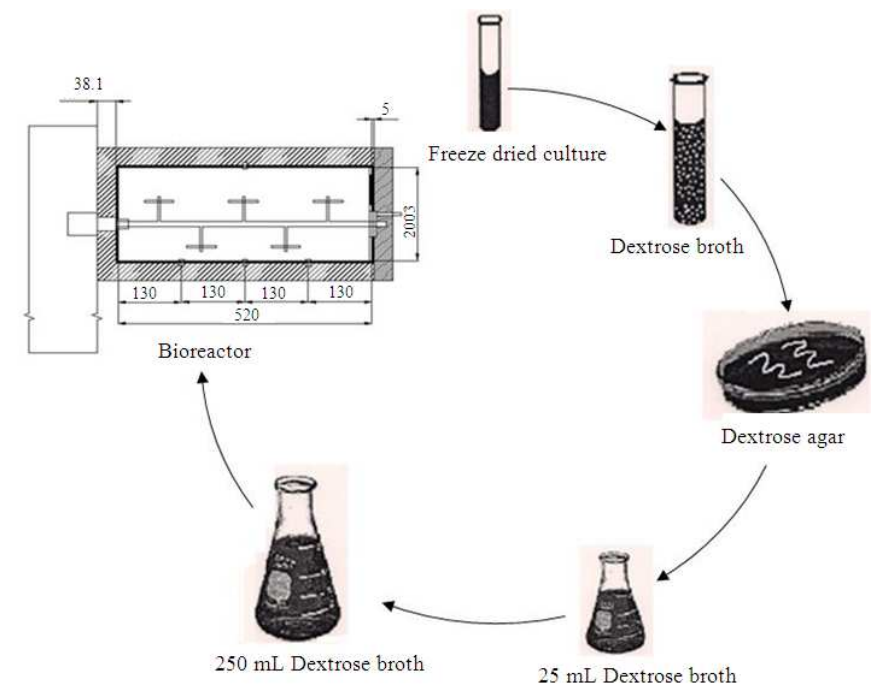

Fig. 3: Steps for preparing the Thermoascus aurantiacus spore suspension 


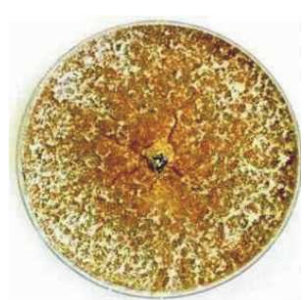

(a)

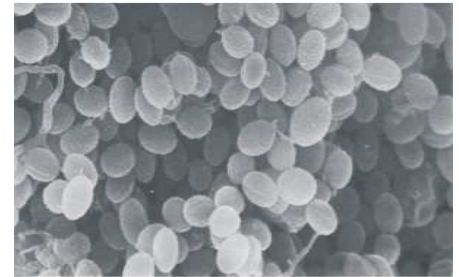

(b)

Fig. 4: Thermoascus aurantiacus (a) Colonies with bright orange colour elliptical on potato dextrose agar (b) Asci containing ascospores

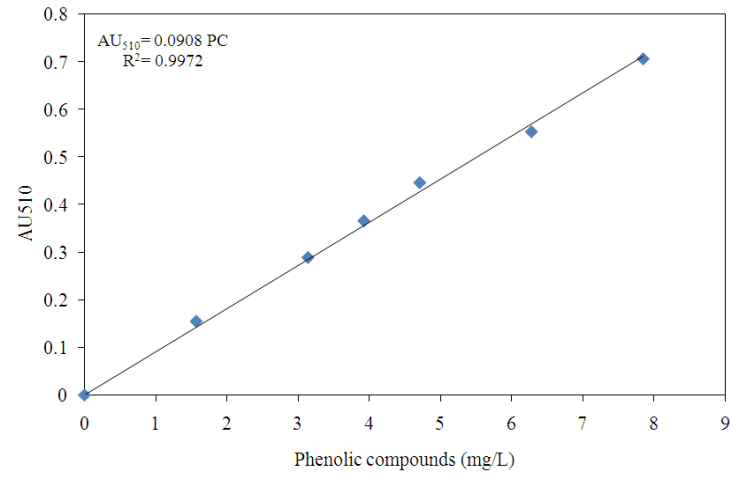

Fig. 5: Standard curve for the phenolic compounds

The Germination Index (GI): The Germination Index (GI) was measured following the procedure described by Iannotti et al. (1994) and Jiang et al. (2006). About $10 \mathrm{~g}$ of compost sample were mixed with 100 mLdistilled water. Ten cress seeds (Lepidium sativum L.) were evenly placed on the filter paper (Whatman ${ }^{\circledR} 40$, Whatman Inc., Clifton, New Jersey) in a sterilized Petri dish. Then, $5.0 \mathrm{~mL}$ of the extract was transferred into the filter paper. Three replicates were carried out for each sample. The Petri dishes were incubated at $25^{\circ} \mathrm{C}$ in the dark for $48 \mathrm{~h}$. The results were evaluated by counting the number of germinated seeds and measuring the length of roots. The Germination Index (GI) was determined as Eq. 2:

$$
\text { GI }(\%)=\frac{\begin{array}{l}
\text { Seed germination }(\%) \times \\
\text { Root length of treatment }(\mathrm{cm})
\end{array} \times 100}{\text { Root length of } \operatorname{control}(\mathrm{cm})}
$$

$\mathrm{CO}_{2}$ Evolution: $\mathrm{CO}_{2}$ evolution was determined as described by Benito et al. (2003). Approximately $25 \mathrm{~g}$ of the material were sampled and pre-incubated at room temperature for 3 days. The moisture content was adjusted to $60 \%$ and each sample was separately sealed in containers containing a beaker with $10 \mathrm{~mL}$ of $1 \mathrm{M}$ $\mathrm{NaOH}$ solution. The samples were incubated at $25^{\circ} \mathrm{C}$ and the $\mathrm{CO}_{2}$ generated was determined by titrating $\mathrm{NaOH}$ solution with $1 \mathrm{M} \mathrm{HCl}$ solution every day for 5 consecutive days. The rate of $\mathrm{CO}_{2}$ evolution was calculated as $\mathrm{mg} \mathrm{C}-\mathrm{CO}_{2} \mathrm{~g}^{-1}$ compost per day.

Cellulose and lignin contents: The cellulose and lignin contents were measured following the Standard Methods published by AOAC (1980) for Acid Detergent Fiber (ADF) and Acid Detergent Lignin (ADL). Cellulose was estimated as the difference between ADF and ADL. Lignin was estimated as the difference between ADL and ash content as described by Yu et al. (2007).

\section{RESULTS}

Temperature: The temperature profile was generated by plotting time series of the average temperature data of the control experiment and the inoculated experiment with inoculation of Thermoascus aurantiacus in as shown in Fig. 6. The fluctuation in the temperature during the thermophilic phase (between 40 and $50^{\circ} \mathrm{C}$ ) was due to the process of adding bio-available carbon source (used cooking oil) which required opening the system every $12 \mathrm{~h}$. The peak temperatures for control and the inoculated experiments were 50 and $48.8^{\circ} \mathrm{C}$, respectively. The temperature was maintained above $45^{\circ} \mathrm{C}$ for 59 and $99 \mathrm{~h}$ and above $40^{\circ} \mathrm{C}$ for 146 and $186 \mathrm{~h}$ for the inoculated and control experiments, respectively. The room temperature was stable around $22-24^{\circ} \mathrm{C}$.

Moisture content: The moisture content decreased gradually during the bioremediation process as shown in Fig. 7. The final moisture contents for the control and inoculated experiments were 42.9 and $48.0 \%$, respectively.

pH: The changes in $\mathrm{pH}$ are shown in Fig. 8. The initial material was acidic (a $\mathrm{pH}$ of 6.0). In the first week of bioremediation, the $\mathrm{pH}$ value increased to the basic range of 7.4-8.5 and then decreased to a weak acidic (5.5-6.8). 
Solids: The changes in volatile solids and ash contents are presented in Fig. 9. The initial volatile solids content of the materials was $805 \pm 10 \mathrm{~g} \mathrm{~kg}^{-1}$ material (dry basis) which decreased slowly resulting in reductions of 4.6 and $0.1 \%$ for the control and the inoculated experiments, respectively. The ash content basically stayed constant at $195 \pm 12 \mathrm{~g} \mathrm{~kg}^{-1}$ material (dry basis) till the end of the bioremediation process as the variations in the final ash contents were within the experimental errors.

Total carbon: The changes in total carbon content are shown in Fig. 10. The initial total carbon was $392 \mathrm{~g}$ $\mathrm{kg}^{-1}$ material (dry basis). The final total carbons for the control and the inoculated experiments were 358 and $386 \mathrm{~g} \mathrm{~kg}^{-1}$ material (dry basis) resulting in total carbon reductions of 8.7 and $1.5 \%$, respectively.

Total Kjeldahl Nitrogen (TKN): The changes in total Kjeldahl nitrogen (TKN) are shown in Fig. 11. The initial TKN was $24.94 \mathrm{~g} \mathrm{~kg}^{-1}$ material (dry basis) which decreased to 12.5 and $17.1 \mathrm{~g} \mathrm{~kg}^{-1}$ material (dry basis) for the control and the inoculated experiments resulting in reductions in TKN of 50.2 and $31.9 \%$, respectively.

C:N Ratio: The changes in C:N ratio (Fig. 12) were calculated from total carbon and total Kjeldahl nitrogen data. The initial $\mathrm{C}: \mathrm{N}$ ratio was 15.6:1. Due to the consumption of continuously added used cooking oil and the rapid consumption of nitrogen by microorganisms (to metabolize bio-available carbon for cell growth and energy production), the $\mathrm{C}$ : $\mathrm{N}$ ratio increased reaching 28.6: 1 and 22.6: 1 for the control and the inoculated experiments, respectively.

Lignocellulose: The results of the degradation of cellulose and lignin are shown in Table 2. The initial content of cellulose was $24.8 \pm 1.5 \%$ which decreased after 15 days to 19.2 and $20.2 \%$ for the control and inoculated experiments resulting in reductions of 19.8 and $20.2 \%$, respectively. The initial content of lignin was $19.8 \pm 0.9 \%$ which decreased after 15 days to 16.3 and $17.2 \%$ for the control and the inoculated experiments resulting in reductions of 17.7 and $13.1 \%$, respectively.

Phenolic compounds: The initial concentration of PC was $0.222 \pm 0.010 \mathrm{mg} \mathrm{g}^{-1}$ material (dry basis). During the bioremediation process, the concentration of PC decreased gradually in both experimental trials, reaching a final concentration of $0.058 \pm 0.006 \mathrm{mg} \mathrm{g}^{-1}$ material (dry basis) for the control and $0.071 \pm 0.005 \mathrm{mg}$ $\mathrm{g}^{-1}$ material (dry basis) for the inoculated experiment as shown in Fig. 13. The inoculated experimental trial had a lower degradation $(68.0 \%)$ of phenolic compounds than the control experiment (73.9\%).

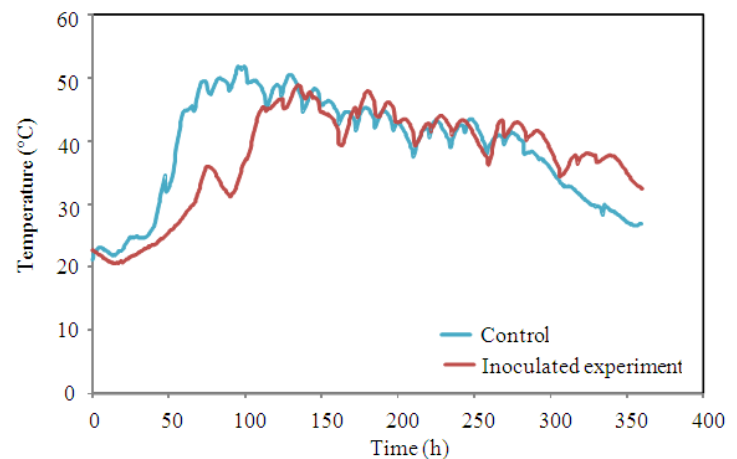

Fig. 6: Temperature profiles

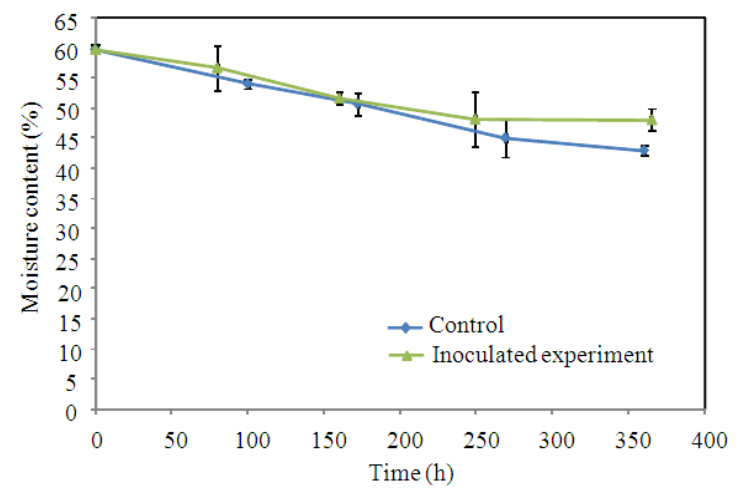

Fig. 7: Changes in moisture content during the bioremediation process

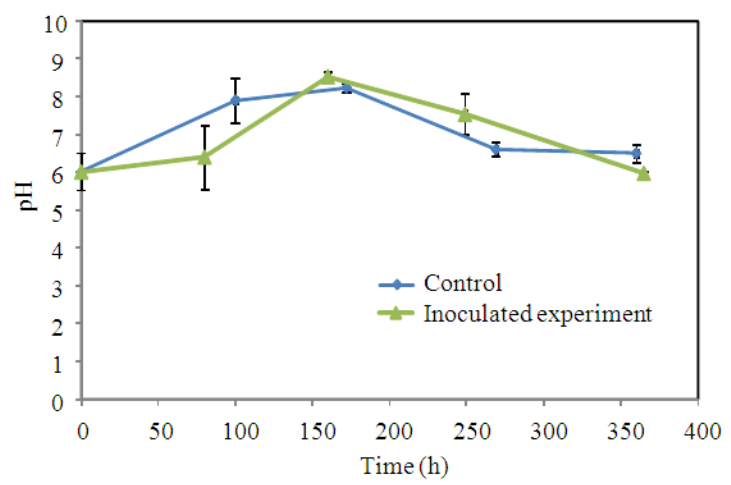

Fig. 8: Changes in the $\mathrm{pH}$ during the bioremediation process

Maturity and stability tests: The maturity and stability of the final bioremediation product were evaluated by analyzing the $\mathrm{CO}_{2}$ evolution (as $\mathrm{mg}$ of $\mathrm{CO}_{2}-\mathrm{C} / \mathrm{g}$ VS-day and $\mathrm{mg}$ of $\mathrm{CO}_{2}-\mathrm{C} / \mathrm{g} \mathrm{C}$-day), the Germination Rate (GR) and the Germination Index (GI) 95 
Am. J. Biochem. \& Biotech., 7 (2): 90-103, 2011

Table 2: Degradation of cellulose and lignin

\begin{tabular}{|c|c|c|c|c|c|c|}
\hline \multirow[b]{2}{*}{ Trial } & \multicolumn{3}{|c|}{ Cellulose Content (\% DM) } & \multicolumn{3}{|c|}{ Lignin Content (\% DM) } \\
\hline & Initial & Final & Degradation* & Initial & Final & Degradation* \\
\hline Control & $24.8 \pm 1.5$ & $19.2 \pm 0.7$ & 22.6 & $19.8 \pm 0.9$ & $16.3 \pm 0.3$ & 17.7 \\
\hline Inoculated experiment & $24.8 \pm 1.5$ & $19.8 \pm 1.2$ & 20.2 & $19.8 \pm 0.9$ & $17.2 \pm 0.7$ & 13.1 \\
\hline
\end{tabular}

\pm Standard deviation: * Percent reduction

Table 3: $\mathrm{CO}_{2}$ evolution, germination rate and germination index

\begin{tabular}{|c|c|c|c|c|c|c|}
\hline \multirow[b]{2}{*}{ Trial } & \multicolumn{2}{|l|}{$\mathrm{CO}_{2}$ Evolution } & \multicolumn{2}{|c|}{ GR $(\%)$} & \multicolumn{2}{|l|}{ GI $(\%)$} \\
\hline & (mg CO${ }_{2}-\mathrm{C} / \mathrm{g}$ VS-d volatile solid-day) & (mg CO${ }_{2}-\mathrm{C} / \mathrm{g} \mathrm{C}-\mathrm{d}$ carbon-day) & Initial & Final & Initial & Final \\
\hline Control & $3.18 \pm 0.19^{*}$ & $6.89 \pm 0.41$ & 0 & 90 & 0 & 20 \\
\hline Inoculated experiment & $4.22 \pm 0.24$ & $8.79 \pm 0.50$ & 3 & 62 & 0 & 5 \\
\hline
\end{tabular}

\pm Standard deviation

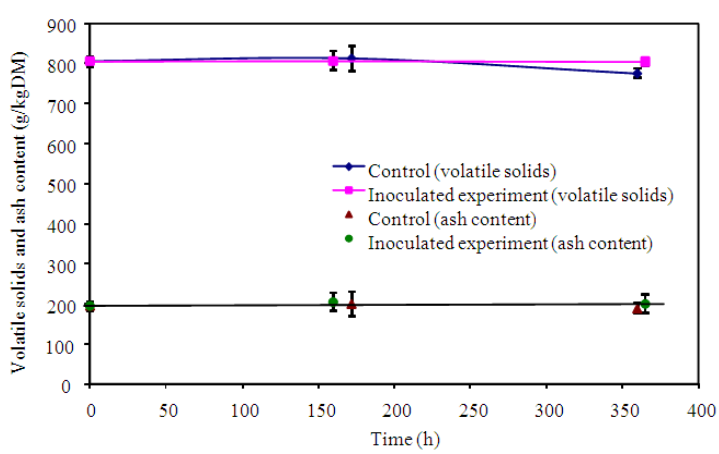

Fig. 9: Changes in volatile solids and ash contents during bioremediation process

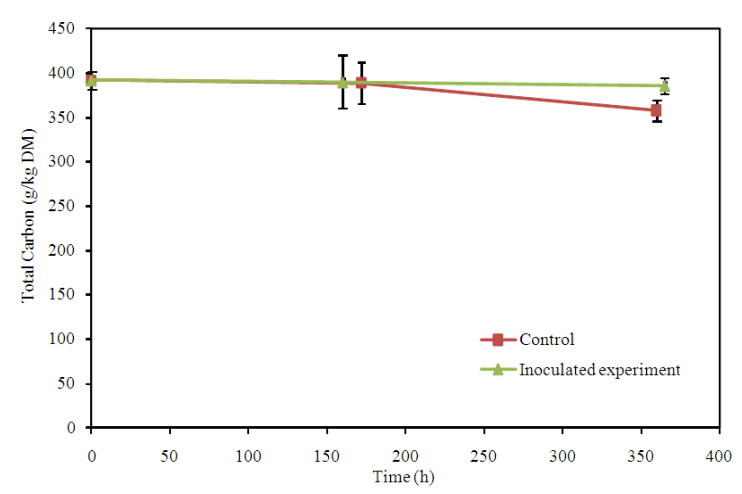

Fig. 10: Changes in total carbon content during the bioremediation process

The $\mathrm{CO}_{2}$ evolution rates from the final product were 3.18 and $4.22 \mathrm{mg} \mathrm{CO}_{2}-\mathrm{C} / \mathrm{g}$ VS-day for the control and inoculate experiments, respectively. The initial GI was $0 \%$ which improved significantly after bioremediation reaching 20 and $5 \%$ for the control and inoculated experiments, respectively.

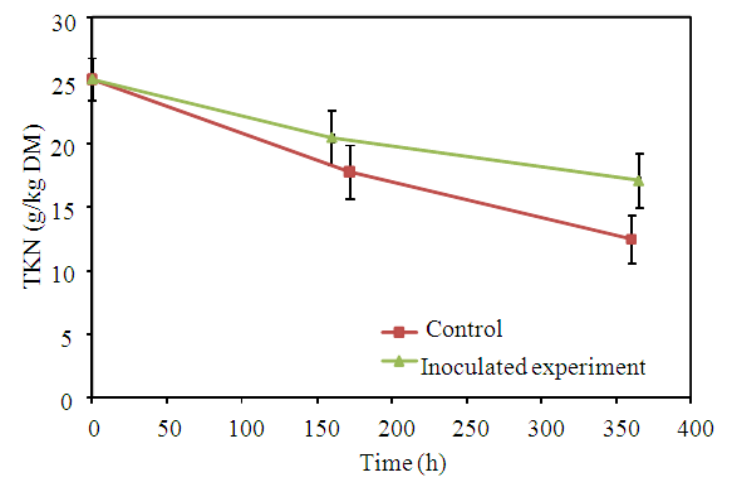

Fig. 11: Changes in TKN content during the bioremediation process

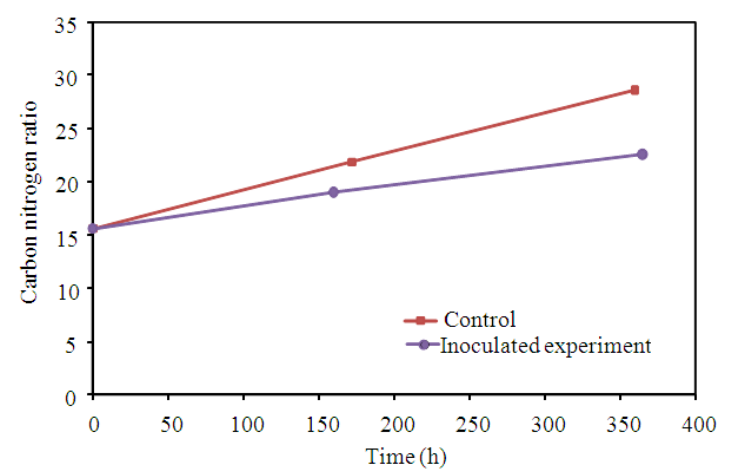

Fig. 12: Changes in $\mathrm{C}: \mathrm{N}$ during the bioremediation process

\section{DISCUSSION}

Temperature: The peak temperature achieved was above $50^{\circ} \mathrm{C}$ in the control bioreactors and $48.8^{\circ} \mathrm{C}$ in the inoculated bioreactors. Loser et al. (1999) used a pilot scale percolator to compost PAH-contaminated pine wood waste with liquid hog manure as a nitrogen and mineral source and obtained a maximum temperature of $42^{\circ} \mathrm{C}$. 


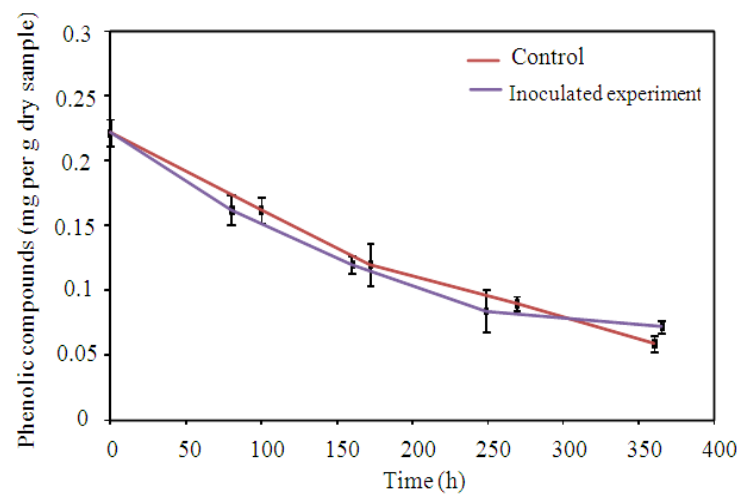

Fig. 13: Degradation of phenolic compounds during the bioremediation process

McMahon et al. (2009) composted a mixture of board waste (C and D wood waste) with poultry manure, green waste, top soil and compost and observed a peak temperature above $70^{\circ} \mathrm{C}$ which is significantly higher than the peak temperature achieved in this study. This could be due to the fact that more nutrients were added in the system (poultry manure), thereby increased the bio-available carbon and nitrogen. Although the addition of used cooking oil maintained the temperature within the thermophilic range for the first few days, the temperature decreased at the end of each trial indicating the decline of bio-available carbon in the composting mixture.

Chen and Chen (1988) reported a very fast growth for Thermoascus aurantiacus at a temperature of 40$50^{\circ} \mathrm{C}$. Cooney and Emerson (1964) reported minimum, optimum and maximum temperatures for Thermoascus aurantiacus growth of 20,45 and $55^{\circ} \mathrm{C}$, respectively. Deploey (1995) reported minimum, optimum and maximum temperatures for the growth of ascospores of $32,47.5$ and $60^{\circ} \mathrm{C}$, respectively. The temperature recorded in this study was within the optimum range of temperature for the growth of Thermoascus aurantiacus.

Moisture content: Water is the media for nutrient transportation and metabolic reactions and, therefore, the availability of nutrients and the contaminant to microorganisms is affected by the water content in their micro-environment (Golueke, 1977; Gajalakshmi and Abbasi, 2008). The optimum moisture content for metabolic activity is in the range of $50-70 \%$ (Tiquia et al., 1996; Epstein, 1997; Gajalakshmi and Abbasi, 2008). In this study, the initial moisture content of the mixture was $59.69 \pm 0.77 \%$ which was within the optimal range. However, the moisture content decreased significantly for both trials during the 15 days of bioremediation. The decreased moisture content was due to the fact that the loss of moisture with the exhaust gas was higher than the moisture produced by metabolic activity as a result of declining bioavailable carbon. According to Haug (1993) and Walker et al. (1999), an intense decrease of moisture content will reduce the metabolic rate and affects the effectiveness of the bioremediation process. If the moisture content is lower than $30 \%$, the microbial activity will be significantly limited (Haug, 1993). The moisture contents in both trials were lower than the minimum optima for metabolic activity but still high enough $(42.9-48.0 \%)$ for the bioremediation process to proceed.

pH: The pH of the mixture was slightly acidic at the beginning of the experiments and increased to 7.9 on the 4th day for the control and then gradually decreased back to a weakly acidic $\mathrm{pH}(6.5)$ by the end of the experiment. For the inoculated experimental trial, the increase in $\mathrm{pH}$ was not significant until the 7 th day (8.5) but followed similar pattern to that of the control experiment. The changes in the $\mathrm{pH}$ were due to the decomposition process and the production of various byproducts. The initial nitrogen content in the material was relatively high $(\mathrm{C}: \mathrm{N}$ ratio of $15.7: 1)$ and the breakdown of organic nitrogen to ammonium resulted in the initial increase in the $\mathrm{pH}$. The final drop in the $\mathrm{pH}$ was due to the formation of organic acids from decomposition of fats and grease (Epstein, 1997). A similar $\mathrm{pH}$ trend was observed by Khan and Anjaneyulu (2006) who explained the rise in $\mathrm{pH}$ as due to the breakdown of protein into ammonia.

The optimum $\mathrm{pH}$ range for the growth of Thermoascus aurantiacus is 3.5-4.5 (Tong et al., 1980; Upadhyay et al., 1984; Grajek, 1988; Maheshwari et al., 2000). Upadhyay et al. (1984) studied the effect of $\mathrm{pH}$ on the growth of Thermoascus aurantiacus at the optimum growth temperature of $50^{\circ} \mathrm{C}$ and found the fungus to grow the fastest within a $\mathrm{pH}$ range of 3.5-4.0 with the shortest lag occurring at $\mathrm{pH} 4.0$ but the growth rate decreased when the $\mathrm{pH}$ was increased from 3.0 to 11.0. Maheshwari et al. (2000) reported an optimum growth of Thermoascus aurantiacus at $\mathrm{pH}$ of 4.5 which then declined with increased $\mathrm{pH}$.

Solids: The degradation of organic matter by microorganisms during bioremediation process is the major energy source for microbial growth (De Bertoldi, 1987; Lemus and Lau, 2002). Thus, the decrease of volatile solids is common in the composting process. Saludes et al. (2007) achieved $43.89 \%$ reduction of volatile solids of dairy cattle manure after 35 days in a controlled thermophilic-mesophilic composting system. 
Lu et al. (2008) reported reductions of volatile solids of $16.71-22.97 \%$ after 7 days of composting barley dregs and sewage sludge. In the current study, $36 \mathrm{~mL}$ of the used cooking oil was added into the system every 12 hrs as bio-available carbon which was utilized by microorganisms. The bioavailable carbon in the feedstock (cellulose material) was limited and as a result the reduction in volatile solid was small ( 0.1 and $4.6 \%$ ). The ash contents stayed relatively constant, the changes observed in the ash were within the experimental errors.

Total carbon: In this study, the reduction in total solids were in the range of $0.1-4.6 \%$. Wang et al. (2003) achieved a total carbon reduction of $14 \%$ while composting sewage sludge with solid food waste in a bioreactor for 5 days. Gomez-Brandon et al. (2008) reported a total carbon reduction of $3.5 \%$ while composting cattle manure for 15 days. Tiquia and Tam (2000) reported total carbon reductions of 50-63\% in turned windrows and $30-54 \%$ in unturned windrows windrow while composting manure for 42 days. Michel et al. (1995) reported a carbon reduction of $24 \%$ while composting yard trimming waste in a bioreactor for 45 days. The higher reductions of total carbon in these studies may be due to the longer composting time and higher biodegradability of the materials used in their experiments.

The $\mathrm{pH}$ recorded in the study was in the range of 5.5-8.5 which is higher than the optimum $\mathrm{pH}$ range of 3.5-4.5 for the optimum growth of Thermoascus aurantiacus. According to Upadhyay et al. (1984) higher $\mathrm{pH}$ will negatively impact the growth of fungus causing it to sporulate. There were significant differences in the total carbon between the control and the inoculated experimental trial. The results indicated a higher rate of decomposition in the control experiment. The reported $\mathrm{pH}$ is however, suitable for the mixed culture of composting microorganisms.

Total Kjeldahl Nitrogen (TKN): The reductions in TKN were more rapid and much higher than the reductions in the total carbon. There was significant difference between the control and the inoculated experiments. A lower reduction of TKN was observed with the inoculated experiment which is in agreement with the volatile solids and total carbon results. Zorpas et al. (1999) reported a TKN reduction of $0.99 \mathrm{mg} \mathrm{g}^{-1}$ (from $2.12-1.13 \mathrm{mg} \mathrm{g}^{-1}$ dry sludge or $46 \%$ ) in the sewage sludge composting process. Alkoaik and Ghaly (2006) observed a TKN reduction of $11.0 \%$ during composting of greenhouse tomato plant residues. Tiquia and Tam (2000) reported a TKN reduction of 50\% during the 168 days of composting of chicken litter in forced- aeration piles. Kumar et al. (2008) reported a TKN reduction of only $0.53-0.64 \%$ during the composting of paddy straw which is low in nitrogen content.

C: N Ratio: The C:N ratio decreases in a biological decomposition system because: (a) the organic carbon is oxidized to $\mathrm{CO} 2$ faster than ammonium is oxidized to NO3- and (b) nitrogen can remain relatively stable if the balance between mineralization of organic nitrogen to $\mathrm{NH} 4$ and the immobilization of $\mathrm{NH} 4$ to organic nitrogen (microbial growth) is maintained during the process (Wang et al., 2003; Alkoaik, 2005). However, if the initial concentration of nitrogen is high, the decrease in nitrogen will surpass the decrease in total carbon resulting in a higher $\mathrm{C}$ : $\mathrm{N}$ ratio. The higher temperature and/or longer thermophilic phase will result in higher rate of organic nitrogen decomposition and increased nitrogen loss (Bishop and Godfrey, 1983; Tiquia and Tam, 2000; Wang et al., 2003).

Bioremediation/composting that starts with low $\mathrm{C}: \mathrm{N}$ ratio results in significant losses of nitrogen (Tiquia and Tam, 2000; Beck-Friis et al., 2001). Tiquia and Tam (2000) reported a nitrogen reduction of $59 \%$ while composting chicken litter with an initial $\mathrm{C}$ : $\mathrm{N}$ ratio of 14.5:1. Beck-Friis et al. (2001) reported nitrogen reduction of $24-33 \%$ while composting household wastes with an initial C: $\mathrm{N}$ ratios of 21-23:1 under controlled conditions for 22-31 days. Due to the continuous addition of used cooking oil and the rapid consumption of nitrogen by microorganisms for cell growth, the $\mathrm{C}$ : $\mathrm{N}$ ratio increased by 83 and $45 \%$ for the control and the inoculated experimental trial, respectively.

Lignocellulose: The results indicated that the inoculation of cellulolytic-thermophilic microorganisms had little effect on the degradation of cellulose and lignin during the bioremediation process. Yu et al. (2007) studied the degradation of lignocellulose in a laboratory composting system during which the temperature reached a peak of $65^{\circ} \mathrm{C}$ and reported degradation of cellulose and lignin of 11 and $18 \%$ on day 15 and 32 and $23 \%$ on day 45, respectively. Vikman et al. (2002) used controlled composting system to test the biodegradation of lignin-containing pulp and paper products and observed a lignin reduction of approximately $17 \%$ at $35^{\circ} \mathrm{C}, 25 \%$ at $50^{\circ} \mathrm{C}$ and $15 \%$ at $58^{\circ} \mathrm{C}$ on the 15 th day and were $41.8 \%$ at $35^{\circ} \mathrm{C}, 39.6 \%$ at $50^{\circ} \mathrm{C}$ and $24.8 \%$ at $58^{\circ} \mathrm{C}$ on day 45 . The current study resulted in similar degradation of cellulose and lignin but in a shorter period of time. This may be due to the addition of bio-available carbon used cooking oil. 
Thermoascus aurantiacus has been shown to grow efficiently on lignocellulosic biomass as it is capable of producing all cellulolytic and hemocelluloytic enzymes (cellulases, hemicellulases, amylases, pectinases) required for the complete degradation of cellulose and hemicellulose to glucose (Da Silva et al., 2005; Kalogeris et al., 2003; Milagres et al., 2004; Santos et al., 2003; Yu et al., 1987). These enzymes operate at a temperature of $50-55^{\circ} \mathrm{C}$ and acidic $\mathrm{pH}$ (Yu et al., 1987; Adams, 1992). The lack of degradation of cellulose in the experiment augmented with Thermoascus aurantiacus could be the result of higher $\mathrm{pH}$ which may have retarded the production of celluloytic and hemocelluloytic enzymes required for the complete degradation of cellulosic material to glucose.

Phenolic compounds: About 73.9 and $68.0 \%$ of Phenolic Compounds (PC) were degraded after 15 days of bioremediation in the control and the inoculated experiments, respectively. The higher final phenolic compounds observed in the inoculated experimental trial was the result of the lower temperature and shorter thermophilic phase observed with this trial. This is in agreement with reduction in the total carbon, nitrogen and volatile solids.

The degradation of phenolic compounds in wood substrate was reported by Galli et al. (2008) who used white-rot fungus Pleurotus ostreatus to degrade phenolic compounds in creosote-treated wood and observed a decrease of phenol compounds greater than $75 \%$ after 30 days. In the present study, the $68-73 \%$ degradation of PC was achieved in a much shorter period of time. Khan and Anjaneyulu (2006) achieved complete phenolic compounds and benzene degradation after 40 days of composting contaminated soil and sediment.

Stoilova et al. (2008) studied the biodegradation of mixtures of phenolic compounds by monocultures and mixed culture of Thermoascus aurantiacus and Aspergillus awamori and reported a negative interaction between the studied species. Higher reductions of phenolic compounds were obtained with the mono cultures compared to the mixed culture. There have been also some reports on the toixicity of the enzyme xylanase produced by the fungus Thermoascus aurantiacus on animals (Bedford, 2000; Kongbuntad et al., 2006). There is a possibility that this enzyme could also have a negative impact on the composting microorganisms in the inoculated experiment, resulting in a lower reduction in a phenolic compounds in the augmented experiment compared to the control experiment.

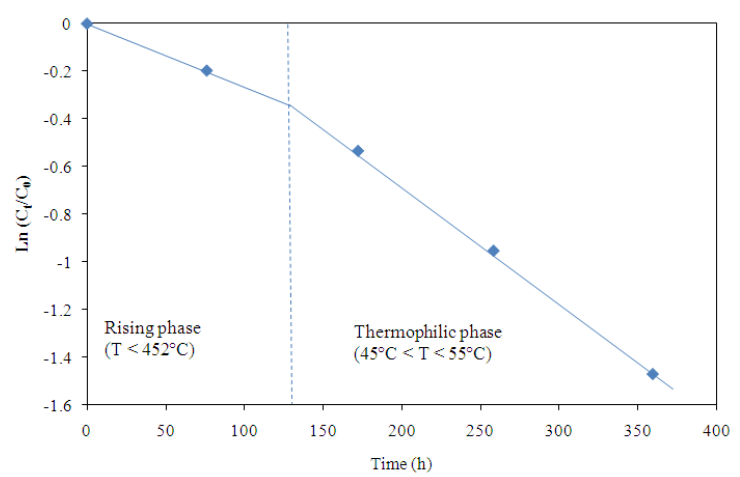

Fig. 14: Graphical determination of rate constant (k) for PC degradation

Table 5: Rate constants for PC degradation

\begin{tabular}{lll}
\hline & Table 5: Rate constants for PC degradation & \\
\hline & Rate constant $\left(\mathrm{h}^{-1}\right)$ & \\
\cline { 2 - 3 } Trial & Rising phase & Thermophilic phase \\
& $\left(\mathrm{T}<45^{\circ} \mathrm{C}\right)$ & $\left(45^{\circ} \mathrm{C}<\mathrm{T}<55^{\circ} \mathrm{C}\right)$ \\
\hline Control & 0.0027 & 0.0047 \\
Inoculated Experiment & 0.0033 & 0.0029 \\
\hline
\end{tabular}

The degradation of organic substrate can be described with the following first order model (Haug, 1993):

$\mathrm{C}_{\mathrm{t}}=\mathrm{C}_{0} \mathrm{e}^{-\mathrm{kt}}$

Where:

$\mathrm{C}_{\mathrm{t}}=$ Concentration of the organic substrate at time $\mathrm{t}$ $(\mathrm{mg} / \mathrm{kg})$

$\mathrm{C}_{0}=$ Initial concentration of the organic substrate $(\mathrm{mg} / \mathrm{kg})$

$\mathrm{K}=$ Rate constant

The value $\mathrm{Ln}\left(\mathrm{C}_{\mathrm{t}} / \mathrm{C}_{0}\right)$ has a linear relationship with the time $\mathrm{t}$ within given temperature range. The linear relationship between $\operatorname{Ln}\left(\mathrm{C}_{\mathrm{t}} / \mathrm{C}_{0}\right)$ and time for phenolic compounds was determined graphically for the mesophilic and thermophilic temperature zones as shown in Fig. 14. The rate constant (k) was determined from the slope of the lines and presented in Table 5. The mesophilic rate constant was 0.0027 and $0.0033 \mathrm{~h}^{-1}$ for the control and the inoculated experimental trials, respectively. During the thermophilic phase, the rate constant of the inoculated experimental trial $\left(0.0029 \mathrm{~h}^{-1}\right)$ was lower compared with the control $\left(0.0047 \mathrm{~h}^{-1}\right)$. The rate constant of $\mathrm{PC}$ degradation was correlated well with reductions in volatile solids, total carbon and TKN.

Maturity and stability tests: The maturity and stability of the bioremediation product were evaluated by analyzing the $\mathrm{CO}_{2}$ evolution rate of the final product 
and comparing the Germination Index (GI) of the final product with that of the feedstock. $\mathrm{CO}_{2}$ evolution is a good indicator to determine the level of microbial activity and the stability of compost while GI provides information about the decomposition of phytotoxic organic substances which indicates the maturity of compost. The lower the $\mathrm{CO}_{2}$ evolution, the more stable the product is and the higher the GI, the more mature the product is (Iannotti et al., 1994; Wu et al., 2000; Boulter-Bitzer et al., 2006). There was significant difference between the control and the inoculated experimental trial in the GI and $\mathrm{CO}_{2}$ evolution rate. The inoculated experimental trial had a higher $\mathrm{CO}_{2}$ evolution rate and a lower GI. This indicates that the product of this experiment was less stable than the control. This result correlates well with the reductions in the volatile solids, total carbon and total kjeldahl nitrogen.

Cooperband et al. (2003) conducted windrow composting of sawdust for 1 year and observed a $\mathrm{CO}_{2}$ evolution of approximately $2 \mathrm{mg} \mathrm{CO}-\mathrm{C} / \mathrm{g}$ final stable compost carbon-day. The $\mathrm{CO}_{2}$ evolution in the current study was higher but the period of bioremediation only lasted 15 days which is much shorter than the processes reported by other researchers. The final product for the control was within the threshold of 8 $\mathrm{mg} \mathrm{CO}_{2}-\mathrm{C} / \mathrm{g}$ carbon-day and is considered stable according to Korner et al. (2003) and Gomez et al. (2006). Rekha et al. (2006) used composting technology for bioremediation of contaminated lake sediments for 14 weeks and reported GIs of $49-95 \%$. The GI of $20-30 \%$ obtained in this study after only a short period of time (15 days) is reasonable. Longer bioremediation may be required to achieve more mature products as the phytotoxicity still existed in the final product in both trials. The product of the control was stable but not mature whereas the product of the inoculated experimental trial was neither stable nor mature. The $\mathrm{pH}$ of both products was 5.5-6.8 which was within the range of 5-7 for stable compost.

\section{CONCLUSION}

The temperatures of bioremediation process reached thermophilic phase $\left(>45^{\circ} \mathrm{C}\right)$ and the mesophilic and thermophilic lag phases were clearly identified. The moisture content decreased significantly indicating that the water produced by microbial respiration did not compensate for the water lost as vapor with the exhaust gases. The final moisture content remained in the range of $43-48 \%$ which is within the optimum range for composting of 40-60\%. Initial increases in the $\mathrm{pH}$ due to the breakdown of organic nitrogen to ammonium and final drops in the $\mathrm{pH}$ due to the formation of organic acids from decomposition of fats and grease and the loss of ammonium with the exhaust gases in the latter stage were observed. Different degradation rates were observed in the mesophilic and thermophilic stages of composting. The control experiment achieved higher reductions of volatile solids, total carbon and TKN indicating a higher level of activity of microorganisms during the composting process compared with the inoculated experimental trial. As a result, higher degradation of phenolic compounds, cellulose and lignin were observed in the control experiment. The stability and maturity of the product of the control experiment were also better than those of the product from the inoculated experimental trial. The inoculation of cellulolytic and thermophilic fungus Thermoascus aurantiacus did not accelerate the bioremediation process in degrading phenolic compounds and may have inhibited the metabolic activity of composting organisms.

\section{ACKNOWLEDGMENT}

This research was supported by the National Science and Engineering Research Council (NSERC) of Canada

\section{REFERENCES}

Adams, P.R., 1992. Growth and amylase production of Thermoascus aurantiacus Miehe. Biotech. Applied Biochem., 15: 311-313. http://cat.inist.fr/?aModele=afficheN\&cpsidt $=5533$ 772

Alkoaik, F. and A.E. Ghaly. 2006. Determination of heat generated by metabolic activities during composting of greenhouse tomato plant residues. J. Environ. Eng. Sci., 5: 137-150. DOI: 10.1139/s05-020

Alkoaik, F., 2005. Fate of plant pathogens and pesticides during composting of greenhouse tomato plant residues. Unpublished dissertation in partial fulfillment of the requirements for the degree of Doctor of Philosophy, Dalhousie University.

AOAC, 1980. Official Methods of Analysis. 1st Edn., Washington, ISBN: 0935584145.

ASTM, 2007a. D 4442-07. Direct Moisture Content Measurement of Wood and Wood-Base Materials. Philadelphia, PA.

ASTM, 2007b. D 1783-01 (Reapproved 2007). Standard Test Methods for Phenolic Compounds in Water. Philadelphia, PA.

ATSDR. 2002. Toxicological Profile for Wood Creosote, Coal Tar Creosote, Coal Tar, Coal Tar Pitch and Coal Tar Pitch Volatiles. Agency for Toxic Substances and Disease Registry, 2009. U.S. Department of Health and Human Services. http://www.atsdr.cdc.gov/toxprofiles/tp85.pdf 
Beck-Friis, B., S. Smars, H. Jonsson and H. Kirchmann. 2001. Structures and Environment: Gaseous emissions of carbon dioxide, ammonia and nitrous oxide from organic household waste in a compost reactor under different temperature regimes. J. Agric. Eng. Res., 78: 423-430. DOI: 10.1006/jaer.2000.0662

Bedford, M.R., 2000. Exogenous enzymes in monogastric nutrition: Their current value and future benefits. Anim. Feed Sci. Tech., 86: 1-13. http://cat.inist.fr/?aModele $=$ afficheN\&cpsidt $=1452$ 806

Bedient, P.B., A.C. Rodgers, T.C. Bouvette, M.B. Tomson and T.H. Wang, 1984. Ground-water quality at a creosote waste site. Ground Water, 22: 318-329. DOI:

$10.1111 / \mathrm{j} .1745-$ 6584.1984.tb01404.x

Benito, M., A. Masaguer, A. Moliner, N. Arrigo and R.M. Palma, 2003. Chemical and microbiological parameters for the characterisation of the stability and maturity of pruning waste compost. Biol. Fertility Soils, 37: 184-189. DOI: 10.1007/s00374003-0584-7

Bishop, P.L. and C. Godfrey, 1983. Nitrogen variations during sludge composting. BioCycle, 24: 34-39.

Borazjani, H., S. Diehl and H.A. Stewart, 2000. Composting of wood wastes: Plywood and sawmill residue. http://fwrc.msstate.edu/pubs/composting.pdf

Boulter-Bitzer, J.I., J.T. Trevors and G.T. Boland, 2006. A polyphasic approach for assessing maturity and stability in compost intended for suppression of plant pathogens. Applid Soil Ecol., 34: 65-81. DOI: 10.1016/j.apsoil.2005.12.007

Brienzo, M., V. Arantes and A.M.F. Milagres, 2008. Enzymology of the thermophilic ascomycetous fungus Thermoascus aurantiacus. Funal BioL. Rev., 22: 120-130. DOI: 10.1016/j.fbr.2009.04.001

CCME, 2005. Canadian Council of Ministers of the Environment. Guidelines for Compost Quality. http://www.ccme.ca/assets/pdf/compostgdlns_1340 e.pdf

CEPA, 1994. Canadian Environmental Protection Act. Priority Substances List Assessment Report. Environment Canada. Health Canada. http://www.hc-sc.gc.ca/ewhsemt/pubs/contaminants/psl1lsp1/hydrocarb_aromat_polycycl/index-eng.php

Carter, M.R. and E.G. Gregorich, 2008. Soil Sampling and Methods of Analysis. 2nd Edn., Canadian Society of Soil Science, CRC Press, Boca Raton, FL., ISBN: 0849335868, pp: 1224.
Chen, G.Y. and Z.C. Chen, 1988. Thermoascus aurantiacus. http://www.bcrc.firdi.org.tw/fungi/fungal_detail.jsp ?id=FU200802030020

CICAD, 2004. Concise International Chemical Assessment Document 62. Coal Tar Creosote. World Health Organization, Geneva. http://libdoc.who.int/publications/2004/924153062 6.pdf

Cooney, D.G. and R. Emerson, 1964. Thermophilic Fungi: An Account of their Biology, Activities, and Classification. 1st Edn., W.H. Freeman, San Francisco, pp: 188. http://books.google.com.pk/books?id=rv0UAQAA IAAJ \&dq=Thermophilic + fungi: + An + account + of $+t$ heir+biology,+activities+and+classification \&hl=en \&ei=iEFXTq7XD8S8rAeT88TJCg\&sa=X\&oi=boo k_result\&ct=result\&resnum $=1 \&$ ved $=0$ CCkQ6AEw AA

Cooperband, L.R., A.G. Stone, M.R. Fryda and J.L. Ravet, 2003. Relating compost measures of stability and maturity to plant growth. Compost Sci. Utilization, 11: 113-124. http://cat.inist.fr/?aModele $=$ afficheN\&cpsidt=1489 9661

Deploey, J.J., 1995. Some factors affecting the germination of Thermoascus aurantiacus ascospores. Mycologia, 87: 362-365. http://www.jstor.org/stable/3760833

Epstein, E., 1997. The Science of Composting. 1st Edn., Technomic Pub. Co, Lancaster, Penns, ISBN: 1566764785, pp: 487.

Gajalakshmi, S. and S.A. Abbasi, 2008. Solid waste management by composting: State of the art. Critical Rev. Env. Sci. Technol., 38: 311-400. DOI: 10.1080/10643380701413633

Galli, E., E. Brancaleoni, F.D. Mario, E. Donati and M. Frattoni.et al., 2006. Mycelium growth and degradation of creosote-treated wood by basydiomycetes. Chemosphere, 72: 1069-1072. PMID: 18501950

Golueke, C.G., 1977. Biological reclamation of solid waste. Rodale Press, Emmaus, PA. pp: 1-272. ISBN: 13: 978-0878571581

Gomez, R.B., F.V. Lima and A.S. Ferrer, 2006. The use of respiration indices in the composting process: A review. Waste Man. Res., 24: 37-47. DOI: 10.1177/0734242X06062385

Gomez-Brandon, M., C. Lazcano and J. Domínguez, 2008. The evaluation of stability and maturity during the composting of cattle manure. Chemosphere, 70: 436-444. DOI: 10.1016/j.chemosphere.2007.06.065 
Grajek, W., 1988. Production of protein by thermophilic fungi from sugar-beet pulp in solidstate fermentation. Biotech. Bioeng., 32: 255-260. DOI: $10.1002 /$ bit. 260320218

Haug, R.T., 1993. Practical Handbook of Compost Engineering. 1st Edn., CRC-Press, ISBN-10: 0873713737, pp: 717.

Iannotti, D.A., M.E. Grebus, B.L. Toth, L.V. Madden and H.A.J. Hoitink, 1994. Oxygen respirometry to assess stability and maturity of composted municipal solid waste. J. Environ. Quality, 23: 1177-1183.

https://www.agronomy.org/publications/jeq/abstrac ts/23/6/JEQ0230061177? access=0\&view=pdf

Ikarashi, Y., M. Kaniwa and T. Tsuchiya, 2005. Monitoring of polycyclic aromatic hydrocarbons and water-extractable phenols in creosotes and creosote-treated woods made and procurable in Japan. Chemosphere, 60: 1279-1287. DOI: 10.1016/j.chemosphere.2005.01.054

Jiang, X.Y., G.M. Zeng, D.L. Huang, Y. Chen and F. Liu et al., 2006. Remediation of pentachlorophenol-contaminated soil by composting with immobilized Phanerochaete chrysosporium. World J. Micro. Biotech, 22: 909913. DOI: $10.1007 / \mathrm{s} 11274-006-9134-4$

Kalogeris, E., P. Christakopoulos, P. Katapodis, A. Alexiou and S. Vlachou et al., 2003. Production and characterization of cellulolytic enzymes from the thermophilic fungus Thermoascus aurantiacus under solid state cultivation of agricultural wastes. Process Biochem., 38: 1099-1104. DOI: 10.1016/S0032-9592(02)00242-X

Khan, Z. and Y. Anjaneyulu, 2006. Bioremediation of contaminated soil and sediment by composting. Remediation J., 16: 109-122. DOI: 10.1002/rem.20105

Kongbuntad, W., C. Khanongnuch, S. Lumyong, 2006. Efficacy of Xylanase supplementation produced from Thermoascus aurantiacus SL16W in diet on Thai native chicken performance. Int. J. Poultry Sci., 5: 463-469. http://www.docsdrive.com/pdfs/ansinet/ijps/2006/4 63-469.pdf

Korner, I., J. Braukmeier, J. Herrenklage, K. Leikam and M. Ritzkowski et al., 2003. Investigation and optimization of composting processes-test systems and practical examples. Waste Manage., 23: 17-26. DOI: 10.1016/S0956-053X(02)00148-4

Kumar, A., S. Gaind and L. Nain, 2008. Evaluation of thermophilic fungal consortium for paddy straw composting. Biodegradation, 19: 395-402. DOI: 10.1007/s10532-007-9145-3
Lemus, G.R. and A.K. Lau, 2002. Biodegradation of lipidic compounds in synthetic food wastes during composting. Canadian Biosystems Eng., 44: 633639.

http://www.engr.usask.ca/societies/csae/protectedp apers/c0155.pdf

Loser, C., H. Ulbricht, P. Hoffmann and H. Seidel. 1999. Composting of wood containing Polycyclic Aromatic Hydrocarbons (PAHs). Compost Sci. Utili., 7 : 16-32. http://direct.bl.uk/bld/PlaceOrder.do?UIN=067998 $613 \&$ ETOC $=$ RN\&from $=$ searchengine

Lu, L.A., M. Kumar, J.C. Tsai and J.G. Lin, 2008. High-rate composting of barley dregs with sewage sludge in a pilot scale bioreactor. Bioreso. Tech., 99: 2210-2217. DOI: 10.1016/j.biortech.2007.05.030

Maheshwari, R., G. Bharadwaj and M.K. Bhat, 2000. Thermophilic fungi: Their physiology and enzymes. Micro. Molecular Bio. Rev., 64: 461488.

http://mmbr.asm.org/cgi/content/abstract/64/3/461

Mamma, D., D. Hatzinikolaou, D. Kekos, H. Stamatis and E. Kalogeris, 2009. Adsorption of major endoglucanase from Thermoascus aurantiacus on cellulosic substrates. World J. Micro. Biotech., 25: 781-788. DOI: 10.1007/s11274-008-9949-2

McMahon, V., A. Garg, D. Aldred, G. Hobbs and R. Smith et al., 2008. Composting and bioremediation process evaluation of wood waste materials generated from the construction and demolition industry. Chemosphere, 71: 1617-1628. PMID: 18325565

McMahon, V., A. Garg, D. Aldred, G. Hobbs and R. Smith et al., 2009. Evaluation of the potential of applying composting/bioremediation techniques to wastes generated within the construction industry. Waste Manage., 29: 186-196. DOI: 10.1016/j.wasman.2008.02.025

Michel, F.C.J., C.A. Reddy and L.J. Forney, 1995. Microbial degradation and humification of the lawn care pesticide 2,4-dichlorophenoxyacetic acid during the composting of yard trimmings. Applied Environ. Microbiol., 61: 2566-2571. http://www.ncbi.nlm.nih.gov/pmc/articles/PMC167 $528 /$

Milagres, A.M.F., E. Santos, T. Piovan and I.C. Roberto, 2004. Production of xylanase by Thermoascus aurantiacus from sugar cane bagasse in an aerated growth fermentor. Process Biochem., 39: 1387-1391. DOI: $10.1016 /$ S00329592(03)00272-3 
Rekha, P., D.S. Suman Raj, C. Aparna, V.H. Bindu and Y. Anjaneyulu, 2006. Bioremediation of contaminated lake sediments and evaluation of maturity indices as indicators of compost stability. Asian J. Water, Environ. Pollu., 3: 57-68. http://iospress.metapress.com/content/cx8uq2lh9w h26kf7/

Saludes, R.B., K. Iwabuchi, A. Kayanuma and T. Shiga, 2007. Composting of dairy cattle manure using a thermophilic-mesophilic sequence. Biosyst. Eng., 98: 198-205. DOI: 10.1016/j.biosystemseng.2007.07.003

Santos, E.D., T. Piovan, I.C. Roberto and A.M.F. Milagres, 2003. Kinetics of the solid state fermentation of sugarcane bagasse by Thermoascus aurantiacus for the production of xylanase. Biotech. Lett., 25: 13-16. DOI: 10.1023/A:1021709610251

Silva, D.R., E.L. Lago, C.W. Merheb, M.M. Macchione and Y.K. Park et al., 2005. Production of xylanase and CMCase on solid state fermentation in different residues by Thermoascus aurantiacus miehe. Braz. J. Microbiol., 36: 235-241. http://dx.doi.org/10.1590/S151783822005000300006

Stoilova, I., A. Krastanov and H. Bui, 2008. Biodegradation of mixed phenolic compounds by a microbial association of Aspergillus awamori and Thermoascus aurantiacus. Elect. J. Environ. Agric. Food Chem., 7: 2625-2633. http://ejeafche.uvigo.es/component/option,com_do cman/task,doc_view/gid,325/

Tiquia, S.M., N.F.Y. Tam and I.J. Hodgkiss, 1996. Microbial activities during composting of spent pig-manure sawdust litter at different moisture contents. Bioresource Tech., 55: 201-206. DOI: 10.1016/0960-8524(95)00195-6

Tiquia, S.M. and N.F.Y. Tam, 2000. Fate of nitrogen during composting of chicken litter. Environ. Pollu., 110: 535-541. DOI: 10.1016/S02697491(99)00319-X

Tong, C.C., L. Anthony and M.G. Shepherd, 1980. Purification and properties of the cellulases from the thermophilic fungus Thermoascus aurantiacus. Biochem. J., 191: 83-94. http://www.ncbi.nlm.nih.gov/pmc/articles/PMC116 2184/

Upadhyay, J.M., M.S. Farmelo, S.G. Goetz and M.A. Melan, 1984. A new variety of a thermophilic mold, Thermoascus aurantiacus var. levisporus. Mycopathologia, 87: 71-80. DOI: 10.1007/BF00436632

USEPA, 1993. Determination of total Kjeldahl nitrogen by semi-automated colorimetry. EPA Method 351.2 (Reversion 2). Environmental monitoring systems laboratory office of research and development, U.S. Environmental Protection Agency, Cincinnati, Ohiohttp://www.flowinjection.com/files/Total\%20 Kjeldahl\%20Nitrogen\%20351_2.pdf

USEPA, 2001. Total, fixed and volatile solids in water, solids and biosolids. EPA-821-R-01-015. Office of Water, Office of Science and Technology, Engineering and Analysis Division, U.S. Environmental Protection Agency, Washington, DC. http://water.epa.gov/scitech/methods/cwa/bioindica tors/upload/2008_11_25_methods_method_biologi cal_1684-bio.pdf

De Bertoldi, M., 1987. Compost: Production, Quality and Use. 1st Edn., Elsevier Applied Science, London, Engl, ISBN: 10: 1851660992, pp: 853.

Vikman, M., S. Karjomaa, A. Kapanen, K. Wallenius and M. Itavaara, 2002. The influence of lignin content and temperature on the biodegradation of lignocellulose in composting conditions. Applied Microbio. Biotechno., 59: 591-598. DOI: 10.1007/s00253-002-1029-1

Walker, L.P., T.D. Nock, J.M. Gossett and J.S. VanderGheynst, 1999. The role of periodic agitation and water addition in managing moisture limitations during high-solids aerobic decomposition. Process Biochem., 34: 601-612. DOI: 10.1016/S0032-9592(98)00122-8

Wang, J.Y., O. Stabnikova, S.T.L. Tay, V. Ivanov and J.H. Tay, 2003. Intensive bioconversion of sewage sludge and food waste by Bacillus thermoamylovorans. World J. Micro. Biotech., 19: 427-432. DOI: 10.1023/A:1023933212654

Wu, L., L.Q. Ma and G.A. Martinez, 2000. Comparison of methods for evaluating stability and maturity of biosolids compost. J. Environ. Quality, 29: 424429. http://lqma.ifas.ufl.edu/PUBLICATION/Wu00.pdf

Yu, E.K.C., L.U.L. Tan, M.K.H. Chan, L. Deschatelets and J.N. Saddler, 1987. Production of thermostable xylanase by a thermophilic fungus, Thermoascus aurantiacus. Enzyme Micro. Technol., 9: 16-24. DOI: $10.1016 / 0141-0229(87) 90044-5$

Yu, H., G. Zeng, H. Huang, X. Xi and R. Wang et al., 2007. Microbial community succession and lignocellulose degradation during agricultural waste composting. Biodegradation, 18: 793-802. DOI: $10.1007 / \mathrm{s} 10532-007-9108-8$

Zorpas, A.A., A.G. Vlyssides and M. Loizisou, 1999. Dewatered anaerobically-stabilized primary sewage sludge composting: Metal leachability and uptake by natural Clinoptilolite. Commun. Soil Sci. Plant Anal., 30: 1603-1613. http://agris.fao.org/agrissearch/search/display.do?f=2000/US/US00001.xml ;US2000105335 